\title{
The Influence of Intellectual Capital on Firm Value towards Manufacturing Performance in Indonesia
}

\author{
Prof. Dr. Euphrasia Susy Suhendra (Gunadarma University, Indonesia)
}

\begin{abstract}
The aim of this study is to analyse the influence of intellectual capital on firm value through firm performance (profitability, productivity, market valuation and growth). Intellectual capital is measured by using a Value Added Intellectual Coefficient (VAIC ${ }^{\mathrm{TM}}$ ). Firm value is measured by Tobin's Q. The financial performance consists of Return on assets (ROA), Asset turn over (ATO), Market to Book Value (MB) and Earnings per Share (EPS).

Data from this study was obtained from financial statements and annual reports of manufacturing companies that are taken from the Indonesia Stock Exchange. The sample of this study is manufacturing companies listed on the Indonesia Stock Exchange during the year of 2011-2013 for 37 companies. The types of data used are secondary data in the form of annual reports by the manufacturing companies. Empirical analysis is conducted by using Structural Equation Modelling (SEM).

The results of this study indicate that Intellectual capital has a significant effect on profitability, market valuation and growth. Intellectual capital does not significantly affect productivity and firm value. Market valuation significantly affects the firm value. Profitability, productivity and growth do not significantly affect firm value. Furthermore, Intellectual capital which is intervened by the firm performance has a positive effect on firm value.
\end{abstract}

\section{Introduction}

The emergence of "new economy", which in principle is driven by developments in information technology and science also trigger the growth of interest in intellectual capital (IC) (Petty and Guthrie, 2000). One area of interest to both academics and practitioners are related to the usefulness of the IC as an instrument for determining the value of the company (Stewart 1997; Edvinsson and Malone 1997; Sveiby 2001). It has become a vexed issue, which some authors have ensured that the management and reporting systems that have been established during this ongoing basis lost its relevance because it is not able to present information that is essential for executives to manage knowledge-based processes and intangible resources (Bornemann and Leitner, 2002).

The expansion of foreign company into the Indonesian market requires domestic companies to further improve its value and performance. Company need to have the strength of market value as value added, company must corrected its internal condition. One of them is the intellectual ability of the company or intangible capital which can enhance the performance and competitiveness of company (Arifin et al., 2014).

However, it is difficult to measure IC since it is intangible and non-physical in nature. The traditional accounting model, which is conceived for companies operating in an industrial economy, remains focused on physical and financial assets and ignores most IC assets. Interestingly, even the International Accounting Standards/International Financial Reporting Standards (IAS/IFRS), including the ones recently modified by the International Accounting Standards Board, did not contribute to redefining many of the concepts, principles and valuation methods of IC assets. The relative lack of IC accounting recognition and its growing role in the value creation process, imply that financial statements have lost some of their value for shareholders and many other users (Canibano et al., 2000).

Limitations of financial statements in explaining the value of the company pointed to the fact that the economy is no longer a source of value in the form of raw material production, but the creation of the IC. IC includes human capital and structural packed in customer, process, database, brand and system (Edvinsson and Malone, 1997 in Ulum, 2008), and has played an increasingly important role in creating a sustainable competitive advantage for the company (Kaplan and Norton, 2004).

The development of economy increasingly complex, raise the issue in the research field of intellectual capital. One of them is regarding the disclosure of intellectual capital. Intellectual capital disclosures need to be disclosed by a company. According to Goh and Lim (2004) in Wadhikorin (2010) in the presence of an increasing demand for transparency in the capital markets, intellectual capital information helps investors assess the ability of the company to be better.

Taking into consideration the increasing importance of the role played by IC in value creation, Pulic (1998, 2004), with colleagues at the Austrian IC Research Centre, developed a new method to measure companies' IC which they called the "value added intellectual coefficient" (VAIC ${ }^{\mathrm{TM}}$ ). This method is very important since it allows us to measure the contribution of every resource - human, structural, physical and financial - to create VA by the company. 
Pulic (in Solikhah, 2010) states that the VAIC TM deemed to comply the basic needs of the contemporary economy from "measurement system" that shows the true value and performance of a company, because the main objective in the knowledge-based economy is to create value added. Meanwhile, in order to create value added needed right size of physical capital (i.e. monetary funds) and intellectual potential (represented by the employee with all the potential and the ability attached to them). Furthermore (Pulic in Ulum, 2008) states that the intellectual ability (later called the VAIC TM) shows how both of these resources (physical capital and intellectual potential) has been efficiently utilized by the company.

The relationship between intellectual capital to the company's financial performance has been proved by several researchers in Indonesia as well as abroad. In Indonesia, including Ulum (2008) and Kuryanto (2008). Whereas studies abroad, among others, performed by Firrer and William (2003), Chen et al (2005), and Tan et al. (2007). From these studies, it was found mixed results regarding the relationship of intellectual capital to the company's financial performance.

The research by Firrer and William (2003) using the company's performance, the profitability of which is described by return on assets (ROA), productivity is described to the ratio of sales divided by total assets (ATO), and the market value represented by the market to book value ratio (MB). The results suggest that there is no positive effect between intellectual capital and corporate performance.

While the studies by Chen et al (2005) using a variable market to book value ratio on equity (MB) and the company's financial performance is proxied by return on equity (ROE), return on assets (ROA), revenue growth (GR) and employee productivity (EP). The samples used were 4,254 public companies in Taiwan Stock Exchange. Chen et al (2005) proved that intellectual capital affect the value of markets and corporate performance. Similar to the studies of Chen et al (2005), Tan et al (2007) proved that intellectual capital is positively related to financial performance of the company and the company's financial performance in the future.

While the research conducted by Ulum (2008) examine the effect of intellectual capital on the financial performance of 130 banking companies with the Partial Least Square (PLS) method, the company's financial performance in the future, and also examine the effect of the average growth of intellectual capital (ROGIG) on the performance of financial companies in the future. Comparable with the results of Tan et al (2007), the results of studies by Ulum (2008) proved that the intellectual capital affect the company's financial performance and financial performance in the future, but the average growth of intellectual capital (ROGIG) does not affect the performance financial companies in the future.

Furthermore, research conducted by Arifin et al. (2014) who studied the corporate governance and intellectual capital affects the financial performance and firm value. The result indicates Disclosure of Intellectual Capital has significant effect on the Financial Performance and Firm Value. Financial Performance has a significant effect on Firm Value.

Based on previous studies, this research tries to examine the relationship of Intellectual Capital (IC) to firm value through the firm performance. Intellectual capital will be measured using the method developed by Pulic VAIC $^{\mathrm{TM}}$ (1998). Financial performance in this study will use a variable Return on Assets (ROA) to measure the profitability of the company and Asset Turnover (ATO) to measure the productivity of the company. Stock market performance will be using variables Market to Book Value (MB) to measure the market valuation and Earnings per Share (EPS) to measure the growth. Furthermore, the firm value in this study will be measured using Tobin's Q.

\section{Literature}

Intellectual capital is a broad-based term considered synonymous with firm intangible assets. Consensus is lacking on a clear definition of intellectual capital. However, one widely recognized definition describes intellectual capital as: 'material that has been formalized, captured, and leveraged to produce a higher-valued asset' (Stewart, 1997 in Tseng and Goo, 2005). From the definition, it can be concluded that intellectual capital is a resource of knowledge available on the company that eventually bring future economic benefit to the company. So the core of the existence of intellectual capital is the knowledge itself that supported the process of information to establish contact with outsiders.

Of the various kinds of intellectual capital measurement techniques should be selected one measurement. Sveiby (2001) view that "No single method can fulfill all purposes; one must select the method depending on purpose, situation and audience". In this research, intellectual capital measurement technique used is the measurement technique of Pulic models. Intellectual capital in the model Pulic measured by value added (value added) which was created by the physical capital / capital employed (VACA), human capital (VAHU), and structural capital (STVA). The combination of these three value added is symbolized by the name VAIC ${ }^{\mathrm{TM}}$, developed by Pulic (1998; 2004). 
Value Added Capital Employed (VACA) shows the contribution made by each unit of capital employed to value added organization (Ulum, 2008). Value Added Capital Employed is a company's ability to manage resources in the form of capital assets which, if managed properly will improve the financial performance of the company.

Value Added Human Capital (VAHU) shows the contribution made by each dollar invested in the human capital of the organization's human capital value added individually represent knowledge stock of an organization which is represented by its employees (Bontis et al in Ulum, 2008). Human capital is the knowledge, skill, and experience are taken when the employee leaves the company (Starovic and Mark in Astuti, 2005) which includes the individual's knowledge of an organization that is on the employees (Bontis, Crossan and Hulland in Astuti, 2005) generated through competence, attitude, and intelligence (Roos, Edvinson and Dragonetti in Astuti, 2005).

Structural Capital Value Added (STVA), the amount of structural capital needed to produce 1 rupiah of VA and is an indication of how the success of structural capital in the creation of value (Ulum, 2008). Structural capital (capital organization) is an organization or a company's ability to meet the routine process of the company and the structure that supports the efforts of employees to produce optimal intellectual performance and overall business performance, for example: the company's operating systems, manufacturing processes, organizational culture, management philosophy and all forms of intellectual property owned by the company (Sawarjuwono, 2003).

Performance becomes an important thing for management, because the performance is the result of work that can be accomplished by a person or group of people in an organization, in accordance with the authority and responsibilities of each in order to achieve the goals of the organization in question legally, do not violate the law and in accordance with morals and ethics. Performance is a function of the organization's ability to obtain and use resources in a variety of ways to develop a competitive advantage. Performance can be divided into financial performance and non-financial (Hansen and Mowen, 2005).

\section{Methodology Research}

The independent variables in this study using the method of Value Added Intellectual Coefficient (VAIC TM) developed by Pulic (1998) in (Ulum, 2009). VAIC TM is a fundamental measurement basis for independent variable in this study. In this research, intellectual capital is a form of knowledge resources such as customer, employee competence, and where companies can use technology in the process of value creation (Ulum, 2009). Intellectual capital performance as measured by the value added created by physical capital, human capital and structural capital. VAIC TM is a combination of three indicators of value added which can be expressed as follows: (1) Physical Capital (VACA - Value Added Capital Employed). VACA is the ratio between the value added (VA) to the company's equity (CE), this ratio shows the contribution made by each unit of CE to the value added organization. (2) Human Capital (VAHU - Value Added Human Capital). VAHU shows the contribution made by every rupiah invested in $\mathrm{HC}$ against value added organization. The relationship between VA and HC indicates the ability of $\mathrm{HC}$ to create value for the company. (3) Human Capital (VAHU - Value Added Human Capital) VAHU shows the contribution made by every rupiah invested in $\mathrm{HC}$ against value added organization. The relationship between VA and $\mathrm{HC}$ indicates the ability of $\mathrm{HC}$ to create value for the company.

Intervening variable in this study is the financial performance of companies and stock market performance. This variable is a combination of Bontis et al (2000), Firer and Williams (2003), Chen et al study (2005), Zeghal and Maaloul (2010), Tan et al. (2007) and Arifin et al. (2012), as follows (1) Return on Assets (ROA) Profitability ratio that measures the ability of the capital invested in all of its assets to generate profit companies, (2) Asset Turnover (ATO), This ratio measures the overall efficiency of the use of assets to generate income. (3) Market to book value (MB). Market to book value is used as a proxy for the stock market performance, (4) Earnings per Share (EPS) is a ratio that shows how investors can profit earned per share owned.

Dependent variable in this study is the value of a company is measured using Tobin's Q. A modified version of the Tobin q by Chung \& Pruitt (1994) in Wolfe \& Sauaia (2003) was used for consistency between the games Because of their simplified balance sheets. This modified version closely approximates Tobin's original statistic and produces a $96.6 \%$ approximation of the original formulation used by Lindenberg \& Ross (1981) in Wolfe \& Sauaia (2003).

Population and sample in a study needs to be set in order for the research done really get the data as expected. The population in this study is all companies listed on the Stock Exchange in 2011-2013, while the sample is used throughout the manufacturing companies. Manufacturing companies selected for the manufacturing industry has a broad scope. The period of observation in this study is 2011-2013. This year's selection is based on the limitations of the data sources in the form of annual reports in 2014 so it is not possible to be extended study period to 2014 .

The model used in this study is a model of causality or relationships effect. To test the hypothesis that will be proposed in this study, the technique of analysis that will be used is Structural Equation Modeling SEM or 
operated by AMOS. Modeling studies by SEM allows a researcher to answer the research questions that are dimensionally (i.e. measure what the indicators of a concept) and regression (to measure the effect or the degree of relationship between the factors that have been identified dimensions).

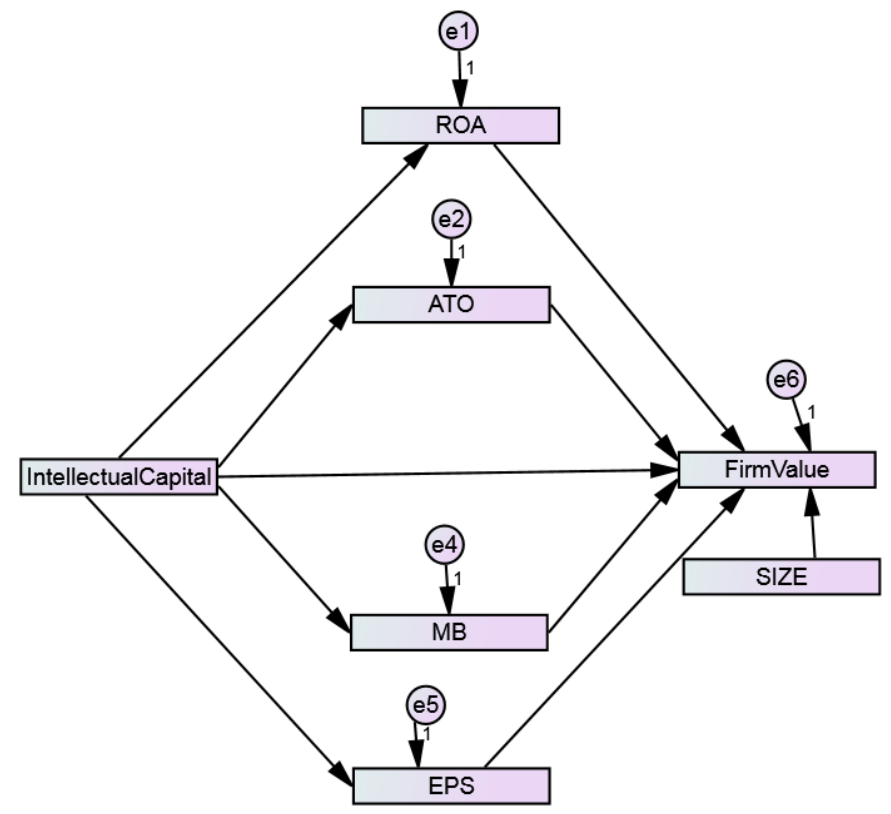

Picture 1. Research Model

\section{Result and Discussion}

Descriptive statistics aims to provide a picture or a description of the data that is seen from the number of samples, the minimum value, maximum value, average value (mean), and standard deviation of each variable. Descriptive statistical analysis was done with the statistical program SPSS version 16. The following describes the research data statistics:

\begin{tabular}{|l|c|c|c|c|c|}
\hline & $\mathbf{N}$ & Minimum & Maximum & Mean & Std. Deviation \\
\hline VAIC & 111 & 1.5788 & 8.3674 & $3.352934 \mathrm{E} 0$ & 1.4756444 \\
\hline ROA & 111 & .0117 & .3120 & .102751 & .0654814 \\
\hline ATO & 111 & .6503 & 2.9577 & $1.327892 \mathrm{E} 0$ & .4575532 \\
\hline MB & 111 & .3540 & 10.4789 & $2.438912 \mathrm{E} 0$ & 2.0366903 \\
\hline EPS & 111 & 2.6569 & $1.6515 \mathrm{E} 4$ & $6.946491 \mathrm{E} 2$ & $2.2116669 \mathrm{E} 3$ \\
\hline a & 111 & .0247 & 6.3750 & $1.226866 \mathrm{E} 0$ & 1.2985313 \\
\hline SIZE & 111 & 25.4942 & 30.9122 & $2.803793 \mathrm{E} 1$ & 1.3145745 \\
\hline
\end{tabular}

Table 1. Descriptive Statistics Source: Secondary data were processed

Based on Table 1 above shows the minimum value of the variable VAIC which is a proxy for the intellectual capital is 1.5788 and the maximum value is 8.3674 as well as the mean is 3.3529 , while the standard deviation is 1.4756. The minimum value of ROA (Return on Assets) is $0.0117(1.17 \%)$ and a maximum value is 0.3120 $(31.2 \%)$ as well as the mean is 0.1027 , while the standard deviation is 0.06548 . The minimum value of Variable ATO (Asset Turnover) is 0.6503 and the maximum value is 2.9577 as well as the mean is 1.3278 , while the standard deviation is 0.4575 . The minimum value of the variable $\mathrm{MB}$ is 0.3540 and the maximum value is 10.4789 as well as the mean is 2.4389 , while the standard deviation is 2.0366 . The minimum value of variable EPS of 2.6569 and the maximum value is 16515.00 as well as the mean is 694.6491, while the standard deviation is 2211.6669. The minimum value of variable $\mathrm{q}$ which is a proxy for firm value measured using Tobin's $\mathrm{Q}$ is 0.0247 and the maximum value is 6.3750 as well as the mean is 1.2268, while the standard deviation is 1.2985. Furthermore, the minimum value of the size of company proxied by the natural logarithm of the book value of total assets is the maximum value is 25.4942 and 30.9122 as well as the mean is 28.0379 while the standard deviation of 1.3145745 .

Analysis of Structural Equation Model (SEM) was performed to test the suitability and statistical tests. The results of data processing for a full analysis of SEM models shown in the figure below: 


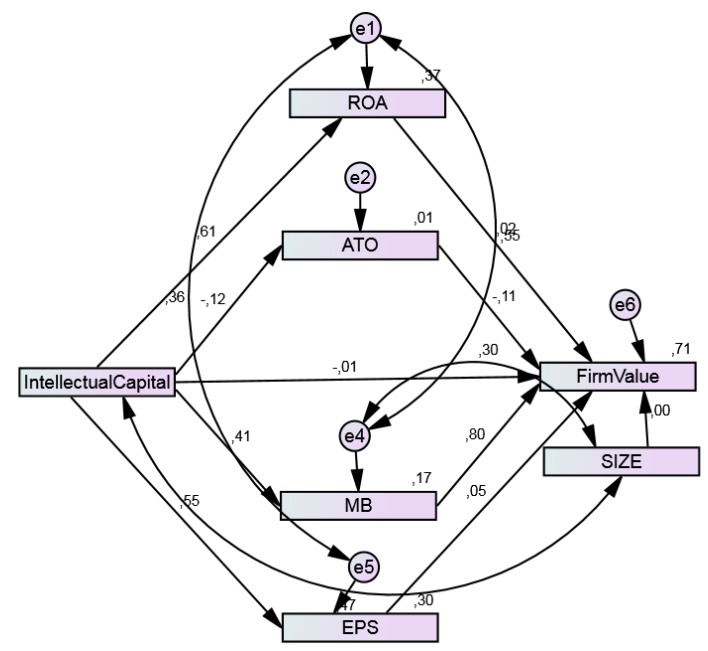

Figure 2. The Results of Structural Equation Model (SEM) Testing

Based on Figure 4.3 indicates that our model has the goodness of fit is good, so that the model deserves. Testing the suitability of the model is summarized in Table 4.12. Based on calculations by the AMOS program for SEM models in this study, resulting indexes of goodness of fit as follows:

\begin{tabular}{|c|c|c|c|}
\hline Goodness of Fit Index & Cut-off Value & The Results Of The Analysis & Evaluation Models \\
\hline Chi-Square & $<24,32$ & 8,570 & Good \\
\hline Probability & $\geq 0,05$ & 0,285 & Good \\
\hline RMSEA & $\leq 0,08$ & 0,045 & Good \\
\hline GFI & $\geq 0,09$ & 0,979 & Good \\
\hline AGFI & $\geq 0,09$ & 0,915 & Good \\
\hline CMIN/DF & $\leq 2,00$ & 1,224 & Good \\
\hline TLI & $\geq 0,95$ & 0,987 & Good \\
\hline CFI & $\geq 0,95$ & 0,996 & Good \\
\hline
\end{tabular}

Table 2. Goodness of Fit Criteria Source: Secondary data were processed

Parameter estimation for testing VAIC (Intellectual Capital) on ROA (Return on Assets) shows the CR value at 8.065 and the probability is 0,001 . Both values are obtained qualify for acceptance $\mathrm{H}_{1}$. CR value is greater than 1.96 and the probability is less than 0.05 . It can be concluded Intellectual Capital has significant effect on return on assets (ROA). It supports research conducted by Chen et al. (2005) and Ulum (2008) which shows that intellectual capital has significant effect on the profitability of the company. ROA illustrates the company's ability to generate profits by using the available resources. Use of company resources efficiently so as to minimize the cost will increase its profit. It also indicates that if a company has a high level of intellectual capital it will have an impact on the profitability rate.

Parameter estimation for testing VAIC (Intellectual Capital) on ATO (Asset Turnover) shows the CR value at -1.272 and probability equal to 0.203 . Both values are obtained do not qualify for acceptance $\mathrm{H}_{2}$ because the smaller CR value of 1.96 and a probability of greater than 0.05 . It can be concluded Intellectual Capital is no significantly effecting on the ATO (Asset Turnover). This is contrary to the research conducted by Chen et al. (2005) and Ulum (2008) which prove that the intellectual capital has significant effect on asset turnover. This might be due to the sample used in this research is a manufacturing company which is to boost the productivity not only human resources needed but also the magnitude of the production capacity of the machine, plant owned and many more.

Parameter estimation for testing VAIC (Intellectual Capital) on MB (Market to Book Value) shows the CR value at 4.719 and the probability is 0.001 . Both values are obtained qualify for acceptance $\mathrm{H}_{3}, \mathrm{CR}$ value is more than 1.96 and the probability is less than 0.05. It can be concluded Intellectual Capital has affect the MB (Market to Book Value). It supports research conducted by Chen et al. (2005) which shows that intellectual capital has significant effect on the market to book ratio (MB). MB reflected the investors about the company's management, liquidity, and future prospects of the company. Therefore, the high level of intellectual capital of the company will increase the level of investor confidence in the company's management, liquidity, and future prospects of the company.

Parameter estimation for testing VAIC (Intellectual Capital) on EPS (Earnings per Share) shows the CR value at 6.826 and the probability is 0.001 . Both values are obtained qualify for acceptance $\mathrm{H}_{4} \mathrm{CR}$ value is more 
than 1.96 and the probability is less than 0.05 . It can be concluded Intellectual Capital has significant effect on EPS (Earning per Share). It supports research conducted by Tan et.al (2007), which states that the intellectual capital significantly affects EPS in manufacturing companies. EPS provides a measure of profitability that combines the decisions from operating, investing and financing. The role of intellectual capital will certainly affect the decision from operating, investing and financing of the company.

Parameter estimation for testing VAIC (Intellectual Capital) on q (Firm Value) shows the CR value at -0.075 and with probability equal to 0.940 . Both values are obtained do not qualify for acceptance $\mathrm{H}_{5}$ because CR value less than 1.96 and a probability more than 0.05 . It can be concluded Intellectual Capital is not significantly effecting on the Firm Value. This is contrary to the research conducted by Arifin et al. (2012) which prove that intellectual capital has positive effect on firm value. This may occur because the creation of a value on the company needed more than just intellectual capital.

Parameter estimation for testing ROA (Return on Assets) on q (Firm Value) shows the CR value at 0.267 and the probability at 0.789 . Both values are obtained do not qualify for acceptance $\mathrm{H}_{6}$ because CR value less than 1.96 and a probability more than 0.05 . It can be concluded Return on Assets is not significantly effects on Firm Value. This indicates that the higher level of profitability of the company does not mean that the value of the company will increase. This is contrary to the research conducted by Arifin et al. (2012) which proved that the return on assets has positive effect on firm value.

Parameter estimation for testing ATO (Asset Turnover) on q (Firm Value) shows the CR value at -2.144 and the probability at 0.032 . Both values are obtained do not qualify for acceptance $\mathrm{H}_{7}$ because although the probability is less than 0.05 but CR value less than 1.96. It can be concluded Asset Turnover is no significantly effecting on Firm Value. This indicates that the high level of productivity does not guarantee the value of the company increased because high productivity without quality control of produced goods would create a bad image of the company.

Parameter estimation for testing MB (Market to Book Value) on q (Firm Value) shows the CR value at 10.258 and the probability at 0.001 . Both values are obtained qualify for acceptance $\mathrm{H}_{8}$ because CR value more than 1.96 and the probability is less than 0.05. It can be concluded that the Market to Book Value has significant effect on Firm Value. This is because the value of the company's market performance can be reflected using the company's stock price. Ratio of market to book value (MB) is to divide the total market capitalization (share price multiplied by the number of outstanding common shares) with a book value of equity owned companies.

Parameter estimation for testing EPS (Earnings per Share) on q (Firm Value) shows the CR value at 0.780 and the probability at 0.435 . Both values are obtained do not qualify for acceptance $\mathrm{H}_{9}$ because CR value less than 1.96 and a probability more than 0.05 . Thus we can conclude that the Asset Turnover is not significantly effecting on Firm Value. This is because EPS information shows the amount of a company's net profit company that is ready to be distributed to all shareholders of the company.

Analysis of the effect intended to see how strong the effect of a variable with other variables either directly, or indirectly. Interpretation of these results will have important meaning to get a clear election strategy. In accordance with the theoretical study and the results of the previous hypothesis testing, intellectual capital will have a direct or indirect effect on firm value. Indirect effect of these variables is to first pass through company's performance, which in turn affect the Firm Value

From these results it turns direct effect of Intellectual Capital to Retun on assets at 0.610, Earning Per Share at 0.545 and Market to Book Value at 0.410. Intellectual Capital turns out to have a negative influence on the Asset Turnover and Value Company. Then highest direct effect occurs in the firm value to Market to Book Value at 0.797 . These results support the regression weights analysis was conducted to the hypothesis test.

Although on results of direct analysis, intellectual capital has a negative effect on the Firm Value but based on the results of the analysis of the indirect effect was found that there was a positive effect of Intellectual Capital on Firm Value at 0,385. This means that, intellectual capital will affect well on Firm Value with the support of good firm performance. High intellectual capital without showing good company performance will not affect the value of the company. Then, good corporate performance will not necessarily increase the value of the company, proved to be only market to book value that significantly affects the firm value.

Total effect analysis is the sum of direct effects and indirect effects that have been done. From the analysis of the total effect turned out that Intellectual Capital effect on Return on Assets, Earnings per Share, Market to Book Value and the Firm Value at $0.610 ; 0.545 ; 0.410$ and 0.380 . Intellectual Capital has a negative influence on the Asset Turnover at -0.120 . The results show that the biggest total effect is in relation of Market to Book Value and Firm Value at 0.797 and the smallest in relation of Intellectual Capital and Asset Turnover at -0120.

\section{Conclusion}

The role of Intellectual capital to improve firm performance and firm value is no doubt. Although direct, intellectual capital has negative impact on firm value, but if it is supported by the firm performance will generate positive results. So, intellectual will affect the firm performance and then will affect firm value.

Based on the analysis has been done in this study conclude that: 
1. Intellectual capital has significant effect on profitability, market valuation and growth.

2. Intellectual capital has no significant effect on productivity and firm value.

3. Market valuation has significant effect on the firm value.

4. Profitability, productivity and growth are not significantly effecting on firm value.

5. Firm performance as intervening variables could affect the relationship between intellectual capital and firm value. This can be seen in the analysis of the effect of direct and indirect.

\section{References}

- Anatan, L., 2005. "E-business Adoption in Small and Medium Enterprises: Opportunities and Challenges in Service-Driven Economy”. 2nd UBAYA Annual Symposium on Management, March 16th-17th, 123-33.

- Arifin et al. 2014. "The Influence of Corporate Governance, Intellectual Capital on Financial Performance and Firm Value of Bank Sub-Sector Companies Listed at Indonesia Stock Exchange in Period 2008-2012". European Journal of Business and Management. Vol. 6 No. 26. pp. 159-167.

- Astuti, Partiwi Dwi. 2005. "Hubungan Intellectual Capital dan Business Performance.” Jurnal MAKSI. Vol 5, 34-58.

- Bontis, N., W.C.C. Keow, S. Richardson. 2000. "Intellectual capital and business performance in Malaysian industries". Journal of Intellectual Capital. Vol. 1 No. 1. pp. 85-100.

- $\quad$ Bornemann, M. and Leitner, K.H. 2002. "Measuring and reporting intellectual capital: the case of a research technology organisation”, Singapore Management Review, Vol. 24 No. 3, pp. 7-19.

- Canibano, L., Garcia-Ayuso, M. and Sanchez, P. 2000. “Accounting for intangibles: a literature review”, Journal of Accounting Literature, Vol. 19, pp. 102-30.

- Chen et al. 2005. "An empirical investigation of the relationship between intellectual capital and firm's market value and financial performance”. Journal of Intellectual Capital, Vol. 6, Issue 2.

- Chen, J., Zhu, Z. and Xie, H.Y. 2004. "Measuring intellectual capital: a new model and empirical study". Journal of Intellectual Capital, Vol. 5 No. 1, pp. 195-212.

- $\quad$ Euis dan Taswan. 2002. "Pengaruh Kebijakan Hutang Terhadap Nilai Perusahaan Serta Beberapa Faktor Yang Mempengaruhinya”. Jurnal Bisnis dan Ekonomi.

- $\quad$ Ferdinand, Augusty. 2006. Metode Penelitian Manajemen. Edisi 2. BP Universitas Diponegoro. Semarang.

- Guthrie, J., Petty, R., Yongvanich, K. and Ricceri, F. 2004. "Using content analysis as a research method to inquire into intellectual capital reporting”. Journal of Intellectual Capital, Vol. 5 No. 2, pp. 282-93.

- Hair, Joseph, F. Anderson, Rolph E. Anderson, R.L. Tatham and W.C. Black. 1998. Multivariate Data Analysis. $5^{\text {th }}$ edition. Upper Saddle River. Prentice-Hal International, Inc. New Jersey.

- Hansen, Don R., and Maryanne M. Mowen. 2005. Management Accounting, 7th Edition. Singapore: SouthWestern, a Division of Thomson Learning Inc.

- Harrison, S., and Sullivan, P.H. 2000. "Profitting form intellectual capital; Learning from leading companies". Journal of Intellectual Capital Vol. 1 No. 1. pp. 33-46.

- Husnan, S., 2000. Manajemen Keuangan-Teori dan Penerapan (Keputusan Jangka Panjeng, BPFE Yogyakarta, pp.7.

- Indriantoro dan Supomo. 2002. Metodologi Penelitian Bisnis. Yogyakarta: BPFE UGM.

- Indriantoro, N., dan B. Supomo. 1999. Metodologi Penelitian Bisnis (Untuk Akuntansi \& Manajemen), edisi pertama, Yogyakarta : BPFE

- Iswati, Sri. 2007. "Memprediksi Kinerja Keuangan dengan Modal Intelektual Pada Perusahaan Perbankan Terbuka di Bursa Efek Jakarta”. Jurnal Ekuitas, Maret, Vol. 11, No. 2, halaman 159-174.

- Iswatia, S. dan Anshoria M. 2007. "The Influence of Intellectual Capital to Financial Performance at Insurance Companies in Jakarta Stock Exchange (JSE)". Proceedings of the 13th Asia Pacific Management Conference, Melbourne, Australia, pp.1393-1399.

- Joia, L.A. 2000. "Measuring intangible corporate assets-linking business strategy with intellectual capital". Journal of Intellectual Capital, Vol.1, No. 1, pp. 68-84

- $\quad$ Kaplan, R.S. dan Northon, D.P. 2004. Strategy maps: Converting intangible assets into tangible outcomes. Boston, MA: Harvard Business School Press.

- Keown. 2004. Manajemen Keuangan : Prinsip-Prinsip dan Aplikasi. Edisi 9, Indeks. Jakarta.

- Kristandl, G. and Bontis, N. 2007. "The impact of voluntary disclosure on cost of equity capital estimates in a temporal setting". Journal of Intellectual Capital, Vol. 8 No. 4, pp. 577-94. 
- Lev, B., Thomas, J. and Nissim, D. 2007. On the informational usefulness of R\&D capitalization and amortization. working paper, available at: www.ssrn.com.

- Maknun, L. 2010. Analisis Pengaruh Frekuensi Perdagangan, Volume Perdagangan, Kapitalisasi Pasar, Dan Trading Day Terhadap Return Saham Pada Perusahaan Manufaktur Yang Terdaftar Di BEI Periode Tahun 2006-2008. Universitas Diponegoro.

- O'Donnell, D. and O'Regan, P. 2000. “The structural dimensions of intellectual capital: emerging challenges for management and accounting”. Southern African Business Review: Special Issue on Information Technology, 4, 2, 14-20.

- OECD. 2008. Intellectual Assets and Value Creation - Synthesis Report, OECD, Paris.

- $\quad$ Petty, R. and J. Guthrie. .2000. "Intellectual capital literature review: measurement, reporting and management". Journal of Intellectual Capital, Vol. 1 No. 2/3, pp. 155-76.

- $\quad$ Pulic, A. 1998. Measuring the performance of intellectual potential in knowledge economy. available at: www.vaic-on.net.

- Pulic, A. 2004. "Intellectual capital-does it create or destroy value?" Measuring Business Excellence, Vol. 8 No. 1, pp. 62-8.

- Riahi-Belkaoui, A. 2003. "Intellectual capital and firm performance of US multinational firms", Journal of Intellectual Capital, Vol. 4 No. 2, pp. 215-26.

- $\quad$ Roos, G., Kristine Jacobsen, and Anna Rylander, 2000. “Towards Improved Information Disclosure on Intellectual Capital”. International Journal of Technology Management, 20 (5/6/7/8), London, United Kingdom.

- Salvatore, Dominick. 2005. Ekonomi Manajerial dalam Perekonomian Global. Salemba Empat: Jakarta.

- Sari, Desfita; Mariso, Muchtar; dan Sjahruddin. 2012. "Pengaruh Assets turnover dan Profit Margin Terhadap Return On Assets Pada Perusahaan Farmasi yang Listing di Bursa Efek Indonesia Tahun 20062010". Repository University of Riau (http://repository.unri.ac.id:80/handle/123456789/1003). Downloaded at December $28^{\text {th }} 2014$

- Sawarjuwono, T. dan Kadir A. 2003. Intellectual Capital: Perlakuan, Pengukuran dan Pelaporan (Sebuah Library Research). Jurnal Akuntansi \& Keuangan Vol. 5, No. 1, Mei 2003: 35 - 57.

- Sawarjuwono, Tjiptohadi dan Agustine Prihatin Kadir. 2003. "Intellectual Capital: Perlakuan, Pengukuran dan Pelaporan (Sebuah Library Research).” Jurnal Akuntansi dan Keuangan. Vol 5, No. 1, 31-51.

- Solikhah, B. 2010. Pengaruh Intellectual Capital terhadap Kinerja Keuangan, Pertumbuhan dan Nilai Pasar pada Perusahaan yang Tercatat di Bursa Efek Indonesia.Universitas Diponegoro.

- Stewart, Thomas A. 2002. Modal Intelektual: Kekayaan Baru Organisasi. Jakarta: PT Elex Media komputindo.

- $\quad$ Sugeng, Imam. 2000. "Mengukur dan Mengelola Intellectual Capital.” Jurnal Ekonomi dan Bisnis Indonesia. Vol 15, No.2, 247-256.

- Sukamulja, Sukmawati. 2004. "Good corporate governance di sektor keuangan. Dampak good corporate governance terhadap kinerja perusahaan”. Benefit, Vol.8, No.1, h.1-25.

- Sveiby 2001. “A Knowledge-based Theory of the Firm to guide Strategy Formulation”. Journal of Intellectual Capital. Vol. 2, No. 4. Pp. 344-358.

- Syamsuddin, Lukman. 2009. Manajemen Keuangan Perusahaan. Edisi Baru. Jakarta: Raja Grafindo Persada.

- $\quad$ Tseng, C.Y. and Goo, Y.J. J. 2005. "Intellectual capital and corporate value in an emerging economy: empirical study of Taiwanese manufacturers". R\&D Management. Vol. 35 No. 2. pp. 187-201.

- Ulum, I. 2007. Pengaruh Intellectual Capital Terhadap Kinerja Keuangan Perusahaan Perbankan Di Indonesia. Tesis Universitas Diponegoro, Semarang.

- Ulum, I; I. Gozhali; dan A. Chariri. 2008. Intellectual Capital dan Kinerja Keuangan Perusahaan; Suatu Analisis dengan Pendekatan Partial Least Squares. Simposium Nasional Akuntansi XI. Pontianak: 23-24 Juli.

- Wahdikorin, A. 2010. Pengaruh Modal Intelektual Terhadap Kinerja Keuangan Perusahaan Perbankan Yang Terdaftar Di Bursa Efek Indonesia (BEI) Tahun 2007-2009. Universitas Diponegoro.

- Ze'ghal, D. 2000. "New assets for the new economy”. FMI Journal, Vol. 11 No. 2, pp. 35-40 (Financial Management Institute of Canada).

- Zeghal, M. dan Maaloul, A. 2010. “Analyzing value added as an indicator of intellectual capital and its consequences on company performance”. Journal of Intellectual Capital, Vol. 11, No. 1, pp. 39-60. 